\title{
OPTIMALISASI PENGELOLAAN DAN PENDISTRIBUSIAN ZAKAT PADA BADAN AMIL ZAKAT DAERAH KABUPATEN CIREBON TERHADAP UPAYA PENINGKATAN KESEJAHTERAAN SOSIAL MASYARAKAT DI KECAMATAN ASTANAJAPURA
}

\author{
Ila Navilah \\ Fakultas Syariah dan Ekonomi Islam \\ IAIN Syekh Nurjati Cirebon \\ Email: navilah23@gmail.com
}

\begin{abstract}
This study starts from thinking that many economic problems faced by people especially Muslims to solve poverty problems. The economic problems should be able to be answered by Zakat system, but right now, economic society welfare isn't spread evenly. Zakat which ought to become one of instruments of economic powe in Indonesia is less to contribute. This phenomena is suitable to be got down, as an effort to spread of economic society welfare. The purpose of this study is to know optimalization of managing and distributing zakat in Cirebon Amil Zakat Agency. This study uses a model of field research, in the form of case studies. While the method used is qualitative. Data collection techniques used include: participant observation, deep interview and study documentation. Data are collected through three techniques then organized, interpreted, and analyzed repeatedly, to the preparation of concepts and abstractions field findings. According to this research it is expected that effort made in optimizing the management and distribution of Zakat funds can able to improve the walfare ofthe community.
\end{abstract}

Keywords: Zakat, Amil, Mustahiq, Muzakki, Management, and Distribution.

\begin{abstract}
Abstrak
Studi ini berawal dari pemikiran banyaknya problem ekonomi yang dialami masyarakat khususnya umat Islam dalam mengatasi masalah kemiskinan. Permasalahan ekonomi tersebut seharusnya bisa dijawab dengan sistem perzakatan, namun justru fenomena yang berkembang saat ini kesejahteraan ekonomi masyarakat terkesan tidak merata. Zakat yang seharusnya menjadi salah satu instrumen pemerataan perekonomian di Indonesia malah kurang memberikan kontribusinya. Fenomena tersebut layak untuk diangkat ke permukaan, sebagai salah satu upaya pemerataan tingkat kesejahteraan ekonomi masyarakat. Tujuan penelitian ini adalah untuk mengetahui optimalisasi pengelolaan dan pendistribusian zakat pada badan amil zakat daerah kabupaten Cirebon. Penelitian ini menggunakan model penelitian lapangan dalam bentuk studi kasus. Sedangkan metode yang digunakan adalah Kualitatif. Teknik pengumpulan data yang digunakan meliputi: observasi partisipan, wawancara mendalam dan studi dokumentasi. Data yang terkumpul melalui ketiga teknik tersebut kemudian diorganisir, ditafsirkan, dan dianalisis secara berulang-ulang, guna penyusunan konsep dan abstraksi temuan lapangan. Berdasarkan penelitian ini diharapkan upaya-upaya yang dilakukan dalam mengoptimalkan pengelolaan dan pendistribusian dana zakat dapat meningkatkan kesejahteraan ekonomi masyarkatnya.
\end{abstract}

Kata Kunci: Zakat, Amil, Mustahiq, Muzakki, Pengelolaan, dan Pendistribusian. 


\section{PENDAHULUAN}

Aktivitas ekonomi sangat penting dalam kehidupan manusia. Hal ini dilakukan manusia untuk mempertahankan kelangsungan hidupnya. Kebutuhan akan sandang pangan, perumahan, perawatan kesehatan, dan pendidikan adalah bagian dari kebutuhan materi yang tidak lepas dari tindakan ekonomi. Segala tindakan ekonomi yang dilakukan manusia harus sesuai dengan tuntunan yang telah diatur dalam AlQuran dan Hadits. Barang-barang materi yang kita miliki tidak lain adalah titipan Allah. Untuk itu, harta yang dimiliki manusia hendaknya dipergunakan di jalan yang di ridhoi Allah. Manusia harus memanfaatkan hartanya dengan sebaik-baiknya. Harta itu juga harus mempuyai manfaat bagi manusia lainnya. Antara fungsi harta, soal kemiskinan, pembagian kekayaan dan keadilan sosial saling berhubungan. Berbagi kekayaan dengan yang lain akan mengurangi beban mereka yang kekurangan.

Dewasa ini, ekonomi Islam sudah berkembang pesat di Indonesia. Semakin banyak bermunculan perbankan syariah. Selain itu, ajakan untuk membayar zakat dan bersedekah juga sudah banyak disosialisasikan. Islam tidak hanya mengajarkan keimanan kepada Allah, tetapi Islam juga mempunyai konsep yang jelas dalam aplikasinya. Zakat adalah salah satunya. Islam menghadirkan konsep zakat sebagai wahana distribusi kekayaan, adanya pajak dalam waktu tertentu, menjaga kehidupan keluarga dengan konsep hukum waris, agar tercipta distribusi yang merata dalam keluarga (al Mishri, 2006). Islam telah mewajibkan umatnya untuk mengeluarkan zakat. Selain untuk menyucikan harta yang kita miliki, zakat juga mempunyai fungsi sosial. Dengan kita melaksanakan kewajiban untuk berzakat maka kita telah membantu mengurangi beban orang lain.

Salah satu upaya untuk mengoptimalkan potensi zakat yang ada di Indonesia adalah dengan disahkannya Undang-undang No. 38 Tahun 1999 tentang Pengelolaan Zakat. Namun demikian, adanya Undang-undang tersebut bukan berarti bahwa pengelolaan zakat bersih dari kendala dan permasalahan yang terjadi di masyarakat, seperti kontribusinya terhadap pengentasan kemiskinan masyarakat dan optimal penggunaannya. Zakat merupakan sumber pendapatan yang signifikan dalam upaya pengentasan kemiskinan. Keterlibatan pemerintah dalam hal pengelolaan dan pendistribusian zakat sangat penting untuk menyalurkan harta zakat secara tepat kepada masyarakat yang membutuhkan.

Berdasarkan studi pendahuluan, penulis menemukan fenomena di lapangan bahwa masyarakat, khususnya para muzakki, sebagian besar belum memanfaatkan fasilitas yang disediakan Badan Amil Zakat Daerah. Hal ini tentu saja akan mengurangi optimalisasi pengelolaan dan pendistribusian dana zakat, sehingga sangat berpengaruh pada upaya peningkatan kesejahteraan ekonomi masyarakat yang menjadi sasaran dana zakat itu sendiri.

\section{LITERATURE REVIEW}

Penelitian tentang optimalisasi pengelolaan zakat juga pernah dilakukan oleh Budi Prayitno (B4A000014) pada tahun 2008 Program Magister Ilmu Hukum Universitas Diponegoro Semarang. Penelitian yang bertema tentang "Optimalisasi Pengelolaan Zakat pada Badan Amil Daerah (Tinjauan terhadap Badan Amil Zakat Daerah Kabupaten Muna Propinsi Sulawesi Tenggara) ini 
dilatarbelakangi oleh potensi zakat di Indonesia belum dikembangkan secara optimal dan belum dikelola secara profesional. Penelitian tersebut dilakukan guna mengetahui tentang optimalisasi UU No. 38 tahun 1999 tentang Pengelolaan Zakat pada Badan Amil Zakat Daerah menyangkut aspek pengumpulan, administrasinya, pendistribusian, monitoring, serta evaluasinya pada Badan Amil Zakat Daerah Kabupaten Muna Propinsi Sulawesi Tenggara.

Peneliti menggunakan metode pendekatan yang merupakan gabungan dari metode penelitian juridis normatif, metode empiris, serta metode kualitatif. Pendekatan normatif dimaksudkan untuk menelaah secara mendalam terhadap asas-asas hukum, peraturan perundang-undangan, yurisprudensi dan pendapat ahli hukum. Pendekatan empiris dilakukan untuk melihat bekerjanya hukum yang menyangkut implementasi ketentuan Pengelolaan Zakat pada Badan Amil Zakat Daerah Kabupaten Muna Sulawesi Tenggara. Sedangkan metode penelitian kualitatif hasil analisis tidak tergantung pada data dari segi jumlah (kualitatif), tetapi data yang ada di analisis dari berbagai sudut secara mendalam (holistik). Teknik analisis yang digunakan adalah analisis kualitatif dengan munggunakan pola pikir induktif. Teknik ini dilaksanakan dengan metode interaktif sebagaimana dikemukakan oleh Mattew B. Milles dan A. Machael Hubermen, yang terdiri dari tiga jenis kegiatan, yaitu reduksi data, penyajian data dan penarikan kesimpulan, yang dapat dilakukan pada saat, sebelum dan selama pengumpulan data.

Hasil penelitian ini menyimpulkan bahwa Pengelolaan dana zakat dan infaq atau shadaqah yang ada pada Badan Amil Zakat Daerah Kabupaten Muna telah dilakukan sesuai ketentuan syariat Islam dan peraturan perundangan yang berlaku. Dengan dikeluarkannya UU No. 38 Tahun 1999 tentang Pengelolaan Zakat, maka penunaian kewajiban zakat lebih terorganisir dan sesuai dengan tujuan diwajibkannya zakat sehingga lebih berhasil guna dan berdaya guna.

Perbedaan peneltian kali ini adalah tentang upaya optimalisasi pengelolaan dan pendistribusian zakat pada Badan Amil Zakat Kabupaten Cirebon terhadap upaya peningkatan kesejahteraan sosial masyarakat di kecamatan astanajapura. Latar belakang penelitian ini diketahui bahwa dikalangan masyarakat Astanajapura, secara umum tidak memanfaatkan fasilitas yang disediakan oleh pemerintah. Masyarakat justru lebih memilih mendistribusikan zakatnya sendiri. Harta zakat yang terkumpul bersifat konsumtif bagi masyarakat, sehingga harta zakat tidak bertahan lama atau lebih cepat habis untuk dimanfaatkan. Melalui model pendekatan field research atau penelitian lapangan, lebih tepatnya berbentuk studi kasus (case-studies), serta menggunakan teknik analisis deskriptif, penelitian ini mencoba untuk menemukan jawaban dari pertanyaan penelitian.

\section{METODE PENELITIAN}

Penelitian ini menggunakan model penelitian lapangan atau field research, lebih tepatnya berbentuk studi kasus (case-studies) tentang optimalisasi pengelolaan dan pendistribusian zakat pada Badan Amil Zakat Kabupaten Cirebon Terhadap Upaya Peningkatan Kesejahteraan Ekonomi Masyarakat di Kecamatan Astanajapura (studi kasus tentang upaya optimalisasi pengelolaan dan pendistribusian zakat di Kecamatan Astanajapura). Teknik pengumpulan data dalam penelitian ini adalah dengan 
menggunakan; pertama, metode observasi partisipan. Melalui metode ini orang melakukan pengamatan dan pencatatan secara sistematis terhadap gejala atau fenomena yang diselidiki, atau disebut juga pengamatan. Metode ini peneliti gunakan untuk mengamati dan memperoleh data tentang pengelolaan dan pendistribusian zakat di Bazda kabupaten Cirebon. Kedua, wawancara mendalam (deep interview). Wawancara mendalam (deep interview) dilakukan dalam rangka mencari validitas data yang peneliti peroleh melalui hasil observasi yang sudah dilakukan. Wawancara digunakan oleh peneliti untuk mencari data tentang optimalisasi pengelolaan dan pendistribusian zakat. Peneliti akan mewawancarai pihak Bazda kabupaten. Ketiga, metode dokumentasi. Peneliti menyelidiki benda-benda tertulis pada seperti buku-buku, majalah, dokumen, peraturan-peraturan, notulen rapat, catatan harian dan sebagainya.

Sumber data yang digunakan adalah data primer dan data skunder. Data primer adalah data yang diperoleh langsung dari sumbernya, diamati dan dicatat untuk pertama kalinya. Data primer dalam penelitian ini diperoleh oleh peneliti dari hasil wawancara dengan pengurus Badan Amil Zakat Daerah kabupaten Cirebon. Data sekunder diperoleh penulis langsung dari pihak yang berkaitan, berupa datadata para muzakki dan mustahiq di Kabupaten Cirebon, dan berbagai literatur yang relevan dan berhubungan dengan pembahasan penelitian.

Metode yang digunakan dalam penelitian ini adalah metode kualitatif, yaitu melalui pengamatan, wawancara, atau penelaahan dokumen. Hasil dari penelitian ini adalah data deskriptif berupa kata-kata tertulis atau lisan dari orang-orang dan perilaku yang diamati. Metode ini menyajikan secara langsung hakikat hubungan antara peneliti dengan responden (Moleong, 2005: 9-10). Berdasarkan data yang telah dikumpulkan, maka proses selanjutnya adalah analisis data. Analisis adalah proses menyusun data agar dapat ditafsirkan. Menyusun data berarti menggolongkannya dalam pola, tema atau kategori (Nasution, 1996:126). Tehnik yang digunakan adalah tehnik analisis deskriptif. Deskriptif adalah data yang dikumpulkan berupa katakata, dan bukan angka-angka. Selain itu, data yang dikumpulkan tersebut berkemungkinan menjadi kunci terhadap apa yang sudah diteliti.

\section{KONSEP DASAR \\ Pengertian Zakat}

Zakat merupakan isim masdar dari kata zakkâ-yuzakkî-tazkiyatan- zakâtan yang berarti berkah, bersih, suci dan berkembang. Terkadang, zakat juga diartikan dengan sebagai sedekah. Dalam istilah Fiqih zakat berarti sejumlah harta tertentu yang diwajibkan oleh Allah swt. untuk diberikan kepada para mustahiq yang disebutkan dalam Alquran. Atau bisa juga berarti sejumlah tertentu dari harta tertentu yang diberikan untuk orang tertentu. Imam Taqyuddin Abi Bakar Ibn Muhammad Alhusaini mendefinisikannya sebagai suatu predikat untuk menyebut kadar jumlah barang tertentu yang diberikan kepada golongan yang telah ditentukan dengan persyaratan tersendiri (Al khusaeni, tt: 172).

Zakat merupakan konsekuensi logis dari prinsip harta milik dalam ajaran Islam yang fundamental, yakni haqqullah (milik Allah yang dititipkan kepada manusia) dalam rangka pemerataan kekayaan. Semakin banyak seseorang mengeluarkan zakat bukan berarti akan menjadikannya pailit, namun sebaliknya, justru akan 
bertambah secara berlipat ganda. Zakat merupakan ibadah yang tidak hanya berkaitan dengan dimensi ketuhanan saja (ghair mahdhah), tetapi juga mencakup dimensi sosial-kemanusiaanyang kerap pula disebut ibadah maliyah ijtima'iyyah. Para ulama sepakat bahwa tiap Muslim yang memiliki kelebihan harta berkewajiban untuk mengeluarkan zakat pada jalur yang telah ditetapkan oleh Allah.

\section{Unsur Zakat}

Menurut Yusuf Al-Qardhawi dalam bukunya yang berjudul Hukum Zakat, mengatakan bahwa dalam zakat terdapat 4 (empat) unsure pokok dalam zakat diantaranya:

1. Orang yang mengeluarkan zakat (Muzakki)

2. Penerima zakat ( Mustahiq )

3. Harta yang wajib di zakati

Pada pasal 4 ayat 2 Undang Nomor 23 Tahun 2011 tentang pengelolaan zakat, harta yang di kenai zakat antara lain :

1. Emas, perak, dan uang;

2. Perdagangan dan perusahaan;

3. Hasil Pertanian, perkebunan, dan perikanan;

4. Hasil tambang;

5. Hasil peternakan;

6. Hasil pendapatan dan jasa;

7. Rikaz.

\section{Pengelola Zakat (Amil)}

Pada pasal 5 Undang Nomor 23 Tahun 2011 tentang Pengelolaan Zakat. Menyatakan bahwa yang di maksud amil zakat adalah pengelola zakat yang di organisasikan dalam suatu badan atau lembaga. Menurut Yusuf Al-Qardhawi mengatakan bahwa dengan adanya amil akan memiliki beberapa keuntungan antara lain :

1. Menjamin kepastian dan disiplin pembayaran zakat;
2. Menjaga perasaan rendah diri pada mustahiq zakat;

3. Untuk mencapai efisiensi dan efektifitas serta sasaran yang tepat dalam penggunaan harta zakat menurut skala prioritas yang ada pada suatu tempat;

4. Memperlihatkan syi'ar Islam dalam semangat penyelenggaraan pemerintahan yang Islami.

Sebaliknya jika zakat di serahkan secara langsung kepada mustahiq adalah sah. Akan tetapi dapat mengabaikan hal yang telah di sebutkan di atas. Selain itu hikmah dan fungsi zakat untuk mewujudkan kesejahteraan umat akan terasa sulit untuk di wujudkan.

\section{Syarat Zakat}

Terdapat beberapa syarat dalam ketentuan berzakat diantaranya adalah:

1. Syarat orang mengeluarkan zakat Orang yang wajib mengeluarkan zakat adalah orang atau badan yang di miliki orang muslim. Pihak yang wajib menunaikan zakat apabila memiliki kelebihan harta yang telah cukup haul dan nishabnya.

2. Syarat harta yang di zakatkan

a. Pemilikan yang pasti, halal, dan baik;

b. Berkembang;

c. Melebihi kebutuhan pokok;

d. Bersih dari hutang;

e. Mencapai nishab;

f. Mencapai masa haul.

3. Syarat penerima zakat

Adapun yang berhak menerima zakat menurut Al-Qur'an surat At Taubah ayat 60 antara lain:
a. Fakir dan Miskin;
b. Amil;
c. Muallaf;
d. Riqab;
e. Gharim;
f. Sabilillah;
g. Ibnu Sabil. 
Tinjauan tentang Kesejahteraan Sosial

Kata sejahtera yang termuat dalam Kamus Besar Bahasa Indonesia tahun 2000, halaman 464 menjelaskan, kata sejahtera diartikan sebagai aman, sentosa, dan makmur, selamat (terlepas dari segala macam ganguan kesukaran dan sebagainya). Sedangkan kata kesejahteraan adalah hal atau keadaan sejahtera yang meliputi keamanan, ketentraman, keselamatan, kesenangan, kemakmuran, dan sebagainya. Kesejahteraan sosial memiliki makna kurang lebih sama dari semua kesejahteraan individual dalam masyarakat. Kesejahteraan sosial sebagai kesejahteraan yang harus di usahakan oleh negara, harus di rumuskan sebagai kesejahteraan yang menunjang kesejahteraan anggota masyarakat, dengan demikian kesejahteraan sosial di rumuskan sebagai jumlah syarat dan kondisi yang perlu tersedia agar anggota masyarakat dapat sejahtera.

Menurut pasal 1 ayat 1 UndangUndang Nomor 11 Tahun 2009 Tentang Kesejahteraan Sosial. Kesejahteraan sosial adalah terpenuhinya kebutuhan moral, spiritual, dan sosial warga negara, agar dapat hidup layak dan mampu mengembangkan diri, sehingga dapat malaksnakan fungsi sosialnya. Dari pengertian tersebut kesejahteraan sosial memiliki 3 (tiga) ruang lingkup yang harus dipenuhi yaitu:

1. Terpenuhinya kebutuhan moral, seperti dapat terpenuhinya pengharagaan antar sesama individu melalui nilai-nilai budaya dan jaminan hukum;

2. Terpenuhinya kebutuhan spiritual, seperti kebebasan masyarakat untuk dapat malaksanakan ibadah atas dasar keyakinanya;

3. Terpenuhinya kebutuhan sosial, seperti terpenuhinya kebutuhan masyarakat akan fasilitas sosial dari negara, seperti halnya masyarakat berhak mendapatkan bantuan sosial, pada saat tempat tinggalnya terkena bencana alam dan lain sebagainya.

Menurut pasal 3 UndangUndang Nomor 11 Tahun 2009 Tentang Kesejahteraan Sosial. Penyelenggaraan kesejahteraan sosial untuk masyarakat memiliki tujuan antara lain:

1. Meningkatkan taraf kesejahteraan, kualitas, dan kelangsungan hidup;

2. Memulihkan fungsi sosial dalam mencapai kemandirian;

3. Meningkatkan ketahanan sosial agar dapat menangani masalah kesejahteraan sosial;

4. Meningkatkan kualitas penyelengagaraan kesejahteraan sosial;

\section{PEMBAHASAN DAN DISKUSI}

A. Konsep Zakat Menurut UndangUndang Nomor 38 Tahun 1999

1. Kedudukan Hukum Zakat

Pada tanggal 23
September 1999 Bangsa
Indonesia telah memiliki hukum
berupa Undang-Undang Nomor
38 Tahun 1999 tentang
Pengelolaan Zakat, yang
pelaksanaan dan pedoman teknis
diatur dalam Keputusan Menteri
Agama Nomor 581 Tahun 1999
yang telah disempurnakan
dengan keputusan Menteri
Agama No. 373 tahun 2003 dan
Keputusan Direktur Jenderal
Bimbingan Masyarakat Nomor
D-29 Tahun 2000.

2. Organisasi Lembaga Pengelola Zakat

Organisasi pengelola zakat diatur dalam Undangundang No. 38 tahun 1999 tentang pengelola zakat. Dalam Bab III pasal 6 dan pasal 7 
menyatakan bahwa lembaga pengelola zakat terdiri atas dua kelompok institusi, yaitu Badan Amil Zakat (BAZ) dan Lembaga Amil Zakat (LAZ) (Pride (Tim Manajemen), 2008:180). Badan Amil Zakat (BAZ) terdiri:

a. Badan Amil Zakat Nasional dibentuk oleh Presiden atas usul Menteri Agama.

b. Badan Amil Zakat Daerah Provinsi dibentuk oleh Gubernur atas usul Kepala Kantor Wilayah Departemen Agama Provinsi.

c. Badan Amil Zakat Daerah Kabupaten/Kota dibentuk oleh Bupati/Walikota atas usul Kepala Kantor Departemen Agama Kabupaten/Kota.

d. Badan Amil Zakat Daerah Kecamatan dibentuk oleh Camat atas usul Kepala Kantor Urusan Agama.

e. Dalam melaksanakan pengumpulan zakat, Badan Amil Zakat sesuai dengan tingkatan membentuk Unit Pengumpul Zakat untuk melayani Muzakki, yang berada pada desa/kelurahan, instansi-instansi pemerintah maupun luar negeri.

Sedangkan Lembaga

Amil Zakat (LAZ) terdiri:
a. Lembaga Amil Zakat tingkat pusat dikukuhkan oleh Menteri Agama
b. Lembaga Amil Zakat tingkat daerah provinsi dikukuhkan oleh Gubernur atas usul Kepala Kanwil Departemen Agama Provinsi.

\section{Fungsi dan Tugas Pokok Pengurus Badan Amil Zakat (BAZ)}

Struktur kepengurusan pada Badan Amil Zakat (BAZ) terdiri dari tiga bagian; yaitu Dewan Pertimbangan, Komisi Pengawas, dan Badan Pelaksana. Setiap bagian mempunyai fungsi dan tugasnya masing-masing, dimana satu sama akan saling mendukung dalam tercapainya pengelolaan dan pendistribusian secara optimal. Berikut struktur organisasi dan rincian fungsi serta tugas pokok pengurus Badan Amil Zakat (BAZ).

Gambar 1. Struktur Organisasi

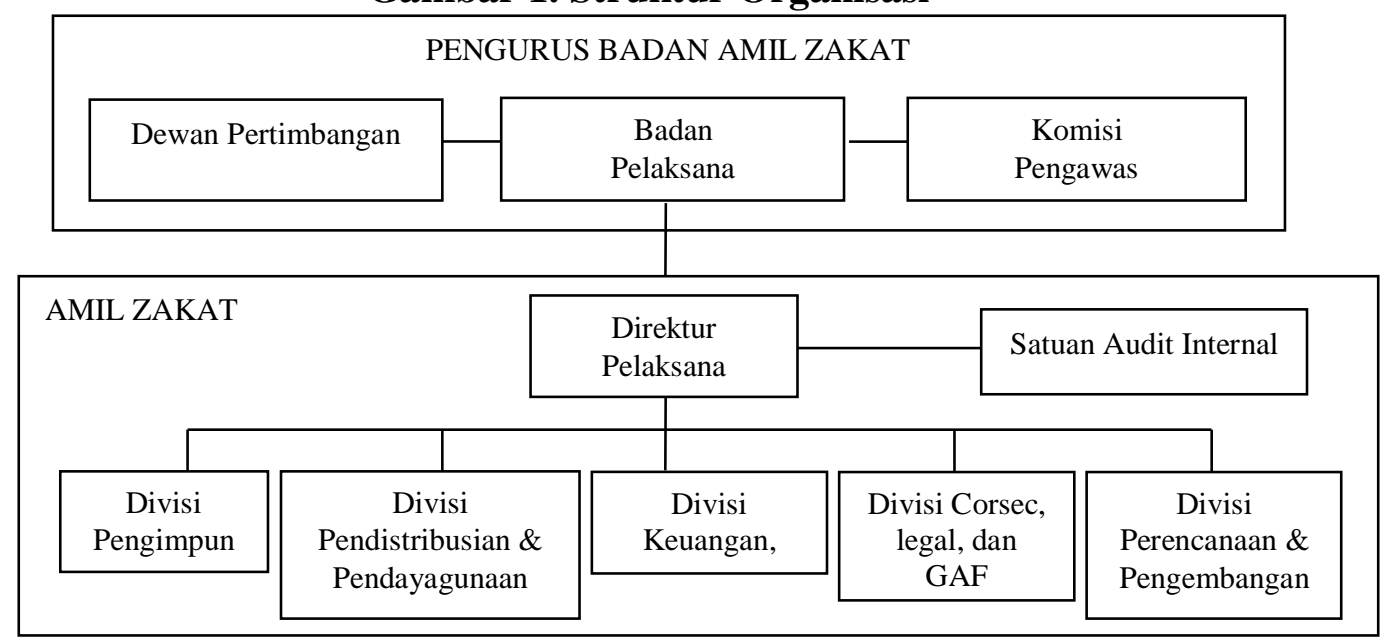


4. Pengelolaan dan Pendistribusian Harta Zakat

Bagian yang bertugas untuk mengelola dan mendistribusikan zakat adalah divisi pengelolaan dan pendayagunaan zakat. Hasil pengumpulan zakat didistribusikan untuk mustahiq sesuai dengan ketentuan syariah. Berdasarkan UndangUndang No. 38 Tahun 1999 pasal 1 ayat 1 tentang pengelolaan zakat, menyatakan bahwa pengelolaan zakat adalah kegiatan perencanaan, pengorganisasian, pelaksanaan, dan pengawasan terhadap pengumpulan dan pendistribusian serta pendayagunaan zakat. Pengelolaan zakat juga mencakup pengelolaan infaq, shadaqah, hibah, wasiat, waris, dan kafarat. Tujuan dari pengelolaan zakat adalah:

a. Untuk meningkatkan pelayanan bagi masyarakat dalam menunaikan zakat sesuai dengan tuntutan agama.

b. Meningkatkan fungsi dan peranan pranata keagamaan, upaya mewujudkan kesejahteraan masyarakat dan keadilan sosial.

c. Meningkatnya hasil guna dan daya guna zakat.

Untuk mewujudkan tujuan tersebut, Badan Amil Zakat sesuai dengan tingkatan membentuk Unit Pengumpul Zakat untuk melayani muzakki, yang berada pada desa/kelurahan, instansiinstansi pemerintah maupun luar negeri. Oleh karena itu, untuk menjamin pengelolaan zakat sebagai amanah agama, dalam undang-undang ini ditentukan adanya unsur pertimbangan dan unsur pengawas.

\section{B. Kondisi Sosial Ekonomi Masyarakat di Kecamatan Astanajapura}

Kecamatan Astanajapura memiliki luas wilayah $25,47 \mathrm{~km}^{2}$. Jarak dari kecamatan ke ibu kota kabupaten sejauh 22,1 km. Batas wilayah kecamatan meliputi sebelah barat berbatasan dengan kecamatan Mundu, sebelah utara berbatasan dengan Laut Jawa, sebelah timur berbatasan dengan kecamatan pangenan, dan sebelah selatan berbatasan dengan kecamatan Lemahabang.

Jumlah penduduk kecamatan Astanajapura berdasarkan data dari kecamatan Astanajapura Dalam Angka tahun 2010 berjumlah 57.640 jiwa, diantaranya 38.577 jiwa adalah laki-laki dan 37.063 jiwa adalah perempuan. Jumlah tersebut tersebar di beberapa desa.

Berdasarkan data tahun 2010 tersebut juga diketahui jumlah kepala keluarga di kecamatan Astanajapura sejumlah 19.731 kepala keluarga. Sebagian besar kepala keluarga memiliki tingkat pendidikan sampai tamat SD dan SMP yaitu sejumlah 11.367 kepala keluarga, 3.026 kepala keluarga berpendidikan sampai tingkat SLTA dan sebanyak 1.003 kepala keluarga mengenyam jenjang pendidikan hingga perguruan tinggi atau akademi. Berikut data selengkapnya. 
Tabel 1. Jumlah Kepala Keluarga Menurut Desa dan Tingkat Pendidikan di Kecamatan Astanajapura

\begin{tabular}{|c|c|c|c|c|c|c|}
\hline \multirow[t]{2}{*}{ No. } & \multirow[t]{2}{*}{ Nama Desa } & \multicolumn{5}{|c|}{ KK Menurut Status Pendidikan } \\
\hline & & $\begin{array}{c}\text { Tdk } \\
\text { tamat } \\
\text { SD }\end{array}$ & $\begin{array}{c}\text { Tamat } \\
\text { SD/ SMP }\end{array}$ & $\begin{array}{l}\text { Tamat } \\
\text { SLTA }\end{array}$ & $\begin{array}{c}\text { Tamat } \\
\text { Akademi/ } \\
\text { PT }\end{array}$ & Jumlah \\
\hline 1 & Munjul & 480 & 1.547 & 245 & 84 & 2.356 \\
\hline 2 & Sidamulya & 368 & 892 & 153 & 21 & 1.434 \\
\hline 3 & Mertapada Kulon & 139 & 580 & 441 & 190 & 1.350 \\
\hline 4 & Mertapada Wetan & 372 & 1.135 & 488 & 135 & 2.110 \\
\hline 5 & Buntet & 566 & 1.021 & 172 & 22 & 1.831 \\
\hline 6 & Kanci Kulon & 472 & 724 & 388 & 38 & 1.622 \\
\hline 7 & Kanci & 121 & 1.053 & 229 & 14 & 1.417 \\
\hline 8 & Astanajapura & 289 & 1.165 & 240 & 249 & 1.943 \\
\hline 9 & Kendal & 131 & 837 & 212 & 43 & 1.223 \\
\hline 10 & Japura Kidul & 750 & 1.098 & 244 & 79 & 2.171 \\
\hline 11 & Japurabakti & 647 & 1.315 & 234 & 78 & 2.274 \\
\hline \multicolumn{2}{|c|}{ Kecamatan } & 4.335 & 11.367 & 3.026 & 1.003 & 19.731 \\
\hline
\end{tabular}

Sumber: UPT PPKB Kec. Astanajapura

Data di atas menunjukkan Tingkat pendidikan yang dimiliki masih tergolong rendah. Hal ini tentunya akan berpengaruh pada tingkat ekonomi masyarakatnya. Tingkat ekonomi masyarakat kecamatan Astanajapura dapat diketahui melalui tingkat kesejahteraan keluarga. Kondisi ekonomi masyarakat kecamatan Astanajapura dapat dilihat pada tabel berikut.

Tabel 2. Jumlah Tahapan Keluarga Sejahtera (KS) Di Kecamatan Astanajapura

\begin{tabular}{|c|c|c|c|c|c|c|c|c|}
\hline \multirow[b]{2}{*}{ Desa } & \multicolumn{2}{|c|}{ Pra KS } & \multicolumn{2}{|c|}{ KS I } & \multirow[t]{2}{*}{ KS II } & \multirow[t]{2}{*}{ KS III } & \multirow{2}{*}{$\begin{array}{c}\text { KS III } \\
\text { Plus }\end{array}$} & \multirow[t]{2}{*}{ Jmlh } \\
\hline & $\begin{array}{l}\text { Eko- } \\
\text { nomi }\end{array}$ & $\begin{array}{l}\text { Non } \\
\text { eko- } \\
\text { nomi }\end{array}$ & $\begin{array}{l}\text { Eko- } \\
\text { nomi }\end{array}$ & $\begin{array}{l}\text { Non } \\
\text { eko- } \\
\text { nomi }\end{array}$ & & & & \\
\hline (1) & (2) & (3) & (4) & (5) & (6) & (7) & (8) & (9) \\
\hline Munjul & 363 & 82 & 639 & 784 & 325 & 104 & 59 & 2.356 \\
\hline Sidamulya & 722 & 100 & 185 & 146 & 188 & 83 & 10 & 1.434 \\
\hline Mertapada Kulon & 341 & 2 & 316 & 128 & 340 & 154 & 69 & 1.350 \\
\hline Mertapada Wetan & 410 & 87 & 780 & 90 & 405 & 231 & 107 & 2.110 \\
\hline Buntet & 603 & 218 & 181 & 234 & 203 & 345 & 47 & 1.831 \\
\hline Kanci Kulon & 365 & 12 & 488 & 48 & 497 & 166 & 46 & 1.622 \\
\hline Kanci & 362 & 219 & 281 & 154 & 227 & 44 & 130 & 1.417 \\
\hline Astanajapura & 755 & 95 & 628 & 113 & 142 & 59 & 151 & 1.943 \\
\hline Kendal & 535 & 40 & 248 & 38 & 273 & 71 & 18 & 1.223 \\
\hline Japura Kidul & 591 & 104 & 752 & 150 & 345 & 122 & 107 & 2.171 \\
\hline Japurabakti & 660 & 51 & 733 & 129 & 460 & 129 & 112 & 2.274 \\
\hline Kecamatan & 5.707 & 1.010 & 5.231 & 2.014 & 3.405 & 1.508 & 856 & 19.731 \\
\hline
\end{tabular}

Sumber: UPT PPKB Kec. Astanajapura

Berdasarkan data tersebut di atas, dapat kita ketahui bahwa sebagian besar masyarakat kecamatan Astanajapura masih berada pada tingkat ekonomi Pra Keluarga Sejahtera dan Keluarga Sejahtera I. Masyarakat Pra Keluarga Sejahtera secara ekonomi sebanyak 
5.707 keluarga dan non ekonomi sebanyak 1.010 keluarga, sedangkan masyarakat dengan tingkat Keluarga Sejahtera I secara ekonomi sebanyak 5.231 keluarga dan secara non ekonomi sebanyak 2.014 keluarga.

Mengukur tingkat kesejahteraan keluarga tentu saja tidak dapat lepas dari kegiatan kerja yang dilakukan oleh masyarakat Kecamatan Astanajapura. Berikut rincian kegiatan kerja yang dilakukan oleh masyarakat Kecamatan Astanajapura.

Tabel 3. Jumlah Kepala Keluarga menurut Desa dan Jenis Kelamin serta Kegiatan Kerja di Kecamatan Astanajapura

\begin{tabular}{|c|c|c|c|c|c|c|c|}
\hline \multirow{2}{*}{ No. } & \multirow{2}{*}{ Desa } & \multicolumn{3}{|c|}{$\begin{array}{l}\text { KK menurut } \\
\text { Jenis Kelamin }\end{array}$} & \multicolumn{3}{|c|}{$\begin{array}{c}\text { KK menurut } \\
\text { Kegiatan Kerja }\end{array}$} \\
\hline & & $\mathbf{L}$ & $\mathbf{P}$ & Jumlah & Bekerja & $\begin{array}{c}\text { Tidak } \\
\text { Bekerja }\end{array}$ & Jumlah \\
\hline 1 & Munjul & 2.023 & 333 & 2.356 & 2.081 & 275 & 2.356 \\
\hline 2 & Sidamulya & 1.201 & 233 & 1.434 & 1.226 & 208 & 1.434 \\
\hline 3 & Mertapadakulon & 1.130 & 220 & 1.350 & 1.136 & 214 & 1.350 \\
\hline 4 & Mertapadawetan & 1.804 & 306 & 2.110 & 1.680 & 430 & 2.110 \\
\hline 5 & Buntet & 1.587 & 244 & 1.831 & 1.570 & 261 & 1.831 \\
\hline 6 & Kanci Kulon & 1.485 & 157 & 1.622 & 1.165 & 457 & 1.622 \\
\hline 7 & Kanci & 1.249 & 168 & 1.417 & 1.269 & 148 & 1.417 \\
\hline 8 & Astanajapura & 1.538 & 405 & 1.943 & 1.499 & 444 & 1.943 \\
\hline 9 & Kendal & 1.082 & 141 & 1.223 & 1.109 & 114 & 1.223 \\
\hline 10 & Japura Kidul & 1.842 & 329 & 2.171 & 1.787 & 384 & 2.171 \\
\hline 11 & Japura Bakti & 1.884 & 390 & 2.274 & 1.722 & 552 & 2.274 \\
\hline & Kecamatan & 16.805 & 2.926 & 19.731 & 16.244 & 3.487 & 19.731 \\
\hline
\end{tabular}

Sumber: UPT PPKB Kec. Astanajapura

Berdasarkan jumlah total kepala keluarga sebanyak 19.731, ternyata yang memiliki pekerjaan sebanyak 16.244 kepala keluarga. Berarti kurang lebih $20 \%$ dari jumlah total kepala keluarga tidak memiliki pekerjaan. Kepala keluarga terbanyak yang tidak bekerja terdapat di desa Japurabakti dengan jumlah 552 kepala keluarga.

Kelancaran kegiatan pemerintahan dan pembangunan sangat bergantung pada tersedianya biaya, baik untuk administrasi maupun kegiatan lainnya. Anggaran pendapatan kecamatan Astanajapura tahun 2010 berasal dari beberapa sumber, yaitu pendapatan asli desa sebesar Rp. 590.821.400, pendapatan desa yang sah dan tidak mengikat sebesar Rp. 1.500.000, penerimaan bagi hasil pajak daerah dan retribusi daerah kabupaten sebesar Rp. 48.500.000, penerimaan bagian dari dana perimbangan keuangan pusat dan daerah sebesar Rp. 675.861.660, sumbangan pihak ke tiga sebesar Rp. 4.000.000, dan pemberian dari pemerintah, baik pusat, provinsi, maupun kabupaten sebesar Rp. 2.228.683.060. Anggaran pendapatan tersebut selanjutnya akan dibelanjakan dalam dua bentuk, yaitu anggaran belanja langsung dan anggaran belanja tidak langsung. Anggaran belanja langsung berupa belanja aparatur pemerintah desa, belanja barang dan jasa, dan belanja modal, sedangankan anggaran belanja tidak langsung berupa belanja aparatur pemerintah desa, belanja bantuan bagi organisasi kemasyarakatan, belanja bantuan social keagamaan, dan belanja tidak terduga. 
C. Optimalisasi Pengelolaan dan Pendistribusian Zakat pada Bazda Kabupaten Cirebon

Bazda Kabupaten Cirebon merupakan wadah yang memberi kemudahan dan membantu masyarakat dalam menunaikan zakat. Sebagai lembaga pengelola dana zakat, Bazda mempunyai peran yang sangat penting bagi optimalnya pengelolaan zakat dalam mensejahterakan masyarakat. Namun demikian, di kecamatan Astanajapura sendiri, peran Bazda masih sangat kecil. Hal ini terlihat dari zakat yang terhimpun baru mencapai $6 \%$. Zakat yang telah terkumpul hanya satu macam zakat saja, yaitu zakat fitrah. Berikut ini jumlah penerimaan dan pembagian zakat di Kecamatan Astanajapura.

Daftar Rekapitulasi Penerimaan Dana Zakat Tahun 1433 H/2012 M

\begin{tabular}{llrrrr}
\hline \multirow{2}{*}{ No. } & Desa/ Kelurahan & \multirow{2}{*}{$\begin{array}{c}\text { Jumlah } \\
\text { UNIT }\end{array}$} & \multirow{2}{*}{$\begin{array}{c}\text { Jumlah } \\
\text { Jiwa }\end{array}$} & Muzakki & \multicolumn{2}{c}{ Jumlah Penerimaan } \\
\cline { 5 - 6 } & & 7723 & 208 & Beras (Kg) & Diuangkan \\
\hline 1 & Astanajapura & 8422 & 144 & 359 & 2.600 .000 \\
2 & Japura Kidul & 4768 & 86 & 281 & 1.795 .000 \\
3 & Kedal & 5243 & 68 & 281 & 1.405 .000 \\
4 & Kanci & 8918 & 72 & 300 & 1.505 .000 \\
5 & Japura Bakti & 7299 & 101 & 422 & 2.110 .0000 \\
6 & Buntet & 9119 & 89 & 369 & 1.845 .000 \\
7 & Mertapadawetan & 6746 & 113 & 469 & 2.345 .000 \\
8 & Kanci Kulon & 8843 & 162 & 658 & 3.290 .000 \\
9 & Munjul & 5354 & 75 & 313 & 1.565 .000 \\
10 & Mertapadakulon & 5440 & 98 & 409 & 2.045 .000 \\
\hline 11 & Sidamulya & $\mathbf{7 7 8 7 5}$ & $\mathbf{2 3 1 7}$ & $\mathbf{4 3 8 1}$ & $\mathbf{2 1 . 9 6 0 . 0 0 0}$ \\
\hline JUMLAH & & & & \\
\hline
\end{tabular}

Pembagian Zakat Fitrah dan Shadaqah Tahun 1433 H/2012 M

\begin{tabular}{llrrrrr}
\hline & \multicolumn{5}{c}{ Pembagian } \\
\cline { 3 - 7 } No. & $\begin{array}{c}\text { Desa/ } \\
\text { Kelurahan UNIT }\end{array}$ & $\begin{array}{c}\text { Fakir } \\
\text { Miskin } \\
\text { Desa/ } \\
\text { Kelurahan }\end{array}$ & $\begin{array}{c}\text { Amilin } \\
\text { Desa/ } \\
\text { Kelurahan }\end{array}$ & $\begin{array}{c}\text { Amilin } \\
\text { Kecamatan }\end{array}$ & $\begin{array}{c}\text { Disetor Ke } \\
\text { BAZ } \\
\text { Kabupaten }\end{array}$ & Jumlah \\
\hline 1 & Astanajapura & 1.560 .000 & 208.000 & 52.000 & 780.000 & 1.820 .000 \\
2 & Japura Kidul & 1.077 .000 & 143.000 & 35.900 & 538.500 & 358.980 \\
3 & Kedal & 843.000 & 112.400 & 28.100 & 421.500 & 2.810 .000 \\
4 & Kanci & 843.000 & 112.400 & 28.100 & 421.500 & 2.810 .000 \\
5 & Japura Bakti & 900.000 & 120.000 & 30.000 & 450.000 & 3.000 .000 \\
6 & Buntet & 1.266 .000 & 168.000 & 42.200 & 633.000 & 4.220 .000 \\
7 & Mertapadawetan & 1.107 .000 & 147.000 & 36.900 & 553.500 & 3.690 .000 \\
8 & Kanci Kulon & 1.407 .000 & 137.000 & 46.900 & 703.500 & 4.690 .000 \\
9 & Munjul & 1.974 .000 & 263.000 & 65.800 & 317.000 & 6.410 .000 \\
10 & Mertapadakulon & 939.000 & 125.000 & 31.300 & 469.000 & 3.130 .000 \\
11 & Sidamulya & 1.227 .000 & 163.000 & 40.900 & 613.500 & 2.045 .000 \\
\hline & JUMLAH & $\mathbf{1 3 . 1 4 3 . 0 0 0}$ & $\mathbf{1 . 7 5 2 . 4 0 0}$ & $\mathbf{4 4 0 . 1 0 0}$ & $\mathbf{6 . 4 0 1 . 5 0 0}$ & $\mathbf{3 4 . 9 8 3 . 9 8 0}$ \\
\hline
\end{tabular}

Sumber : Dokumen Badan Amil Zakat Kecamatan Astanajapura 
Berdasarkan data di atas, dapat diketahui ternyata baru 2.317 jiwa penduduk yang menyalurkan zakatnya melalui BAZDA di kecamatan Astanajapura. Jumlah ini masih sangat sedikit jika dibandingkan dengan jumlah penduduk yang mencapai 77.875 jiwa. Masyarakat di kecamatan Astanajapura pada umumnya mendistribusikan zakatnya secara individual.

Keberadaan BAZDA di kecamatan Astanajapura belum begitu akrab terdengar ditelinga masyarakat. Dengan kata lain masih banyak masyarakat yang belum mengenal adanya BAZDA sebagai lembaga pengelola zakat. Sebaliknya, masyarakat yang sudah mengetahui adanya BAZDA pun belum semuanya memanfaatkan fasilitas yang telah disediakan oleh BAZDA. Dalam wawancara yang telah dilakukan dengan pihak BAZDA kecamatan Astanajapura, hal tersebut disebabkan karena, pertama, keberadaan BAZDA belum mendapat kepercayaan dari masyarakat. Keberadaan BAZDA sangat perlu untuk diketahui oleh masyarakat. Tidak hanya keberadaannya saja, namun programprogram yang telah disusun juga harus disosilisasikan kepada masyarakat. Hal ini amat penting sebagai upaya untuk membujuk dan mengajak masyarakat untuk berzakat melalui BAZDA.

Kedua, popularitas zakat masih kalah saing dibanding dengan ibadah lain seperti shalat, puasa, dan haji. Bahkan pemahaman masyarakat tentang zakat cenderung memisahkannya dari shalat. Bagi kebanyakan masayrakat yang keliru bahwa zakat merupakan ketentuan terpisah dengan shalat perlu diluruskan. Pelurusan persepsi ini sangat penting karena suatu persepsi sangat menentukan tingkah laku perbuatan terhadap sesuatu yang dipersepsinya, demikian juga persepsi masyarakat tentang zakat.

Ketiga, nisab zakat sebagai ketentuan maksimal bukan minimal. Apabila masyarakat bisa merubah persepsinya bahwa nisab zakat yang ditentukan oleh ajaran Islam itu sebagai ketentuan minimal bukan ketentuan maksimal, maka akan banyak sekali dana zakat yang bisa terkumpul.

Dan keempat, zakat hanya dimaknai sebagai ibadah saja. Zakat tidak hanya bermakna ibadah, tapi juga bermakna sosial. Zakat diwajibkan karena mengemban misi persaudaraan Islam yang sejati dan sebagai sarana pengentasan kemiskinan.

Disisi lain persoalan kemiskinan umat Islam selalu ada di mana-mana. Dalam hal ini umat Islam tidak pernah ada usaha melalui zakat untuk memberantas kemiskinan, persoalannya karena tidak adanya persepsi umat Islam bahwa zakat itu diwajibkan dalam Islam adalah untuk memberanatas kemiskinan, sehingga dengan persepsinya itu umat Islam tidak pernah ada usaha yang sungguh-sungguh memanfaatkan zakat itu untuk mengentaskan kemiskinan umat Islam. Kalaupun ada upaya pengentasan kemiskinan melalui ibadah zakat porsinya masih sangat kecil sekali, yaitu oleh sebagian kecil umat Islam yang sadar menggerakkan badan amil zakat. Namun demikian, melalui upaya yang dimulai dari hal yang kecil diharapkan akan mencapai tujuan maksimal bagi badan amil zakat dalam mengoptimalkan dana zakat sehingga akan tercapai kesejahteraan umat.

\section{KESIMPULAN}

Mayoritas Masyarakat Astanajapura memandang bahwa kewajiban menunaikan zakat setiap tahunnya itu hanya terbatas pada zakat fitrah. Hal tersebut menunjukkan bahwa 
pengetahuan dan pengamalan masyarakat terhadap kewajiban menunaikan zakat masih rendah. Selain itu pendistribusian zakat yang dilakukan oleh masyarakat Astanajapura masih bersifat konsumtif dan individual. Artinya, dana zakat yang seharusnya mampu meningkatkan kesejahteraan masyarakat justru malah sebaliknya, 'memanjakan' mustahiq untuk terus berada pada posisinya. Hal ini dikarenakan tingkat kepercayaan muzakki kepada lembaga amil zakat masih sangat rendah yang disebabkan oleh adanya kekhawatiran dari masyarakat bahwa zakat yang diserahkan kepada amil tidak sampai kepada yang berhak menerimanya (mustahiq).

Pengelolaan zakat yang dilakukan oleh Badan Amil Zakat Daerah Kabupaten Cirebon belum optimal. Hal tersebut disebabkan oleh kurangnya sumber daya manusia, baik ditingkat kabupaten maupun kecamatan. Sebagian dari amil zakat tidak menjadikan pekerjaan itu sebagai profesi atau pilihan karir, tapi hanya sebagai pekerjaan sampingan atau pekerjaan paruh waktu. Hal ini menyebabkan kurangnya profesionalisme dalam pekerjaan tersebut. Selain itu, tidak adanya peraturan daerah yang khusus mengatur tentang zakat juga menjadi kendala bagi Badan Amil Zakat Daerah Kabupaten Cirebon dalam optimalisasi pengelolaan dana zakat.

$$
\text { Badan Amil Zakat Daerah }
$$

Kabupaten Cirebon seharusnya lebih meningkatkan koordinasi baik ditingkat kecamatan maupun kabupaten, mengikutsertakan semua pihak, sehingga pengelolaan dan pendistribusian zakat bisa optimal. Perbaikan manajemen pengelolaan zakat, meliputi adanya integrasi sistem pengelola zakat baik itu terkait dengan konsep zakat, profesionalisme pengelola zakat, data base wajib zakat (muzakki) dan penerima zakat (mustahiq). Upaya untuk merubah paradigma atau cara berpikir bahwa pekerjaan sebagai amil hanya pekerjaan paruh waktu juga harus dihilangkan. Amil zakat adalah sebuah profesi. Konsekuensinya seorang amil haruslah profesional. Untuk profesional, salah satunya harus bekerja purna waktu (full time). Untuk itu harus digaji secara layak, sehingga dia bisa mencurahkan segala potensinya untuk mengelola dana zakat secara baik. Selain itu, untuk meningkatkan pengetahuan dan pemahaman masyarakat, maka disarankan agar kepada pihak pengelola zakat untuk mengajak dan merangkul tokoh agama (kyai) untuk dapat memberikan pemahaman yang positif kepada masyarakat tentang zakat serta fungsi dan peran BAZDA.

Perlu adanya perumusan peraturan daerah yang mengatur tentang pengelolaan zakat. Khususnya bagi pemerintah Kabupaten Cirebon. Adanya peraturan daerah akan lebih memperkuat undang-undang zakat yang telah ada sebelumnya. Peraturan ini juga akan menjadikan lembaga-lembaga pengelola zakat lebih bersifat independen.

\section{DAFTAR PUSTAKA}

Abu Azka, Lukman Mohammad Baga. Yusuf al-Qardhawi: Sari Penting Kitab Fikih Zakat. Dept. of Agr. Economics and Business, Massey University Palmerston North, New Zealand. (ebook). 1997.

Al-Ba'ly, Abdul Al-Hamid Mahmud. Ekonomi Zakat. Jakarta: PT Raja Grafindo Persada. 2006.

Ali, Nurudin Mhd. Zakat Sebagai Instrumen Dalam Kebijakan Fiskal. Jakarta: PT Raja Grafindo Persada. 2006. 
Al Mishri, Abdul Sami'. Pilar-pilar Ekonomi Islam. Penerjemah: Dimyauddin Djuwaini. Edisi Pertama. Jakarta: Pustaka Pelajar. 2006.

Al-Jaziri, Abdul-Rahman. Madzahib al Arba'ah Jilid I, Dar al-kotob alIlmiyah. Libanon. 2008.

Arikunto, Suharsimi. Prosedur Penelitian: Suatu Pendekatan Praktek. Jakarta: Rieneka Cipta. 2002.

Dokumen Badan Amil Zakat Kecamatan Astanajapura Kabupaten Cirebon.

Hidayat, Yayat. Zakat Profesi. Cirebon: CV Pangger. 2007.

Hafidhuddin, Didin. Zakat dalam Perekonomian Moderen. Jakarta: Gema Insani Press. 2002.

Ibn Hajar Al Asqolani. tt. Bulughul Maram. Daar Akhya Al Kutubul 'Arobiyah.

Inayah, Gazi. Teori Komprehensip tentang Zakat dan Pajak. Yogyakata: Tiara Wacana. 2003.

Irfan Mahmud Ra'ana. System Ekonomi Pemerintahan umar Ibn alKhatab. terj. Mansuruddin Djoely. Jakarta: Pustaka Firdaus. 1990.

Karim, Adiwarman Azwar. Sejarah Pemikiran Ekonomi Islam. Jakarta: PT. Raja Grafindo Persada. 2006.

Kecamatan Astanajapura Dalam Angka tahun 2010

Kementerian Agama RI. 2011. Petunjuk Pelaksanaan Kemitraan dalam Pengelolaan Zakat. Direktorat Jenderal Bimbingan Masyarakat Islam dan Direktorat Pemberdayaan Zakat.

Khaf, Monzer. Zakah Management in Some Muslim Societies. Jeddah: King Fahd National Library. 2000.

Mannan, M. Abdul. Teori dan Praktek Ekonomi Islam. Yogyakarta: PT Dana Bakti Primayasa. 1997.
Moleong, Lexy J. Metodologi Penelitian Kualitatif. Bandung: PT Remaja Rosdakarya. 2005.

Mufraini, M. Arif. Akuntansi dan Manajemen Zakat. Jakarta: Kencana Prenada Media Group. 2006.

Muhammad bin Qosim al-Ghozi. tt. Fath al- Qorib al-Mujib. Maktabah al-Syarqiyah. Indonesia.

Nasution, S. Metode Penelitian Naturalistik-Kualitatif. Bandung: Tarsito. 1996.

Prayitno, Budi. Optimalisasi Pengelolaan Zakat pada Badan Amil Daerah (Tinjauan terhadap Badan Amil Zakat Daerah Kabupaten Muna Propinsi Sulawesi Tenggara). Semarang: Program Magister Ilmu Hukum Universitas Diponegoro. 2008.

Pride (Tim Manajemen). Kompilasi Perundang-undangan tentang Ekonomi Syariah. Jakarta: Gaung Persada Press. 2008.

P3EI. Ekonomi Islam. Jakarta: PT Raja Grafindo Persada. 2008.

Rakhmat, Jalaluddin. Islam Aktual: Refleksi Sosial Seorang Cendikiawan Muslim. Bandung: Mizan. 2004.

Ridwan, Ahmad Hasan, Pemberdayaan Zakat, Majalah Tazkiah, edisi Januari-Maret 2008.

Suaidi, Jurisdictie, Jurnal Hukum dan Syariah, Volume 1, Nomor 2. Fakultas Syari'ah UIN Maliki Malang. Desember 2010

Sudarsono, Heri. Bank dan Lembaga Keuangan Syariah. Yogyakarta: Ekonisia. 2008.

Taqiyyuddin, Abi Bakar Ibn Muhammad Alkhusaeni. tt. Kifayatul Akhyar. Daar Akhya Al Kutubul 'Arobiyah. 